\title{
Methylsiloxanes Release from One Landfill through Yearly Cycle and Their Removal Mechanisms (Especially Hydroxylation) In Leachates
}

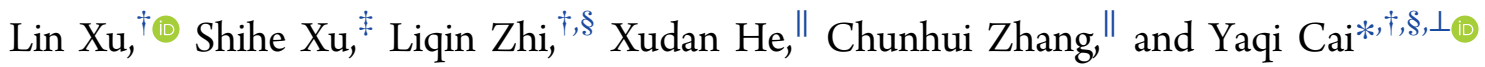

${ }^{\dagger}$ State Key Laboratory of Environmental Chemistry and Ecotoxicology, Research Center for Eco-Environmental Sciences,

Chinese Academy of Sciences, Beijing 100085, China

"Toxicology \& Environmental Research and Consulting (TERC), The Dow Chemical Company, Midland, Michigan 48674, United States

${ }^{\S}$ University of Chinese Academy of Sciences, Beijing 100049, China

"School of Chemical \& Environmental Engineering, China University of Mining \& Technology (Beijing), Beijing, 100083, China

${ }^{\perp}$ Institute of Environment and Health, Jianghan University, Wuhan 430056, China

\section{Supporting Information}

ABSTRACT: In one yearly cycle (2016), D4 and D5 were detected in biogas samples $\left(n=36,0.105-2.33 \mathrm{mg} / \mathrm{m}^{3}\right)$ from a Chinese municipal landfill, while D4-D6 were detected in influents/effluents of leachate storage pond ( $n=72$, $<$ LOQ-30.5 $\mu \mathrm{g} / \mathrm{L})$. Mass loads of cVMS in both biogas $(591-6575 \mathrm{mg} / \mathrm{d}$ ) and leachate influents $(659-5760 \mathrm{mg} / \mathrm{d})$ increased from January to July (summer), and then decreased from July to December (winter). Removal experiments indicated that 1 ) hydrolysis and volatilization were predominant removal mechanism for D4 and D5, respectively, in leachate storage pond, responsible for their more significant removal (94.5-100\%) in August; 2) indirect phototransformation $\left(t_{1 / 2}=25.5-87.0\right.$ days $)$, such as hydroxylation by $\mathrm{OH}$ radical generated in leachates, was the predominant $(50.0-75.5 \%)$ removal pathway for D6, which led to the largest removal efficiencies $(65.2-73.7 \%)$ in June, the month with the largest sun light intensity and highest photosensitizer

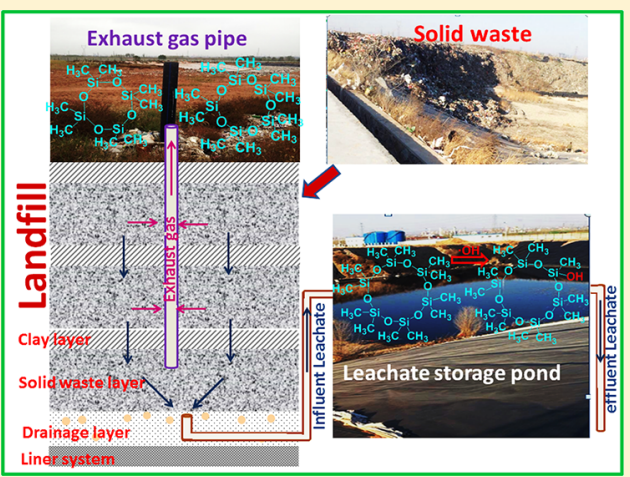
(e.g., $\mathrm{Fe}^{2+}$ and $\mathrm{NO}_{3}^{-}$) concentrations. Monohydroxylated products of D5 and D6, D4TOH and D5TOH, were detected in leachate effluents (39.6-187 ng/L) during May-July. Compared to D5 and D6, volatilization half-lives of D4TOH (86.3 days) and D5TOH (177 days) in leachates were 2.9 and 1.4 times longer, while their hydrolysis half-lives (7.50 days for D4TOH and 21.5 days for D5TOH) were 7.1 and 10 times shorter, respectively.

\section{INTRODUCTION}

Cyclic volatile methylsiloxanes (cVMS) - including octamethylcylotetrasiloxane (D4), decamethylcylopentasiloxane (D5), and dodecamethylcyclohexasiloxane (D6) - were the impurities of polydimethylsiloxane (PDMS), which have vast usage in both industrial and personal consumer products as lubricant, defoamer and electrical insulating agent, etc. ${ }^{1-3}$ In addition, some cVMS (especially D5) could be directly applied in personal care products. ${ }^{1-3}$ Because usage of cVMS-containing products could lead to their environment emission, ${ }^{1-3}$ environment occurrence and fate of cVMS had attracted attention of scientists.

During usage by general population, cVMS in some consumer products would be directly released to air (about 90\%) and wastewater (about 10\%). ${ }^{1-3}$ Hence they could exist in air, water, and biota samples closed to municipal areas. ${ }^{4-10}$ Different from those in the above products, large amount of cVMS in other PDMS-based products such as elastomers and sealants may, via solid waste disposal, enter municipal landfills ${ }^{1-3}$ where up to $95 \%$ of municipal solid waste collected worldwide was disposed. ${ }^{11}$ For example, according to reported emission rates of PDMS-based products and residual monomer contents in these products, ${ }^{1-3}$ D4-D6 in elastomers and sealants may account for $50.1-65.6 \%$ of their total emission from all PDMS-based products in European Union. In addition, despite lack of relevant data, cVMS in personal care product, through disposal of cVMScontaining municipal sludge, may also transfer to landfill. Overall, cVMS emission and fates in landfills are important for understanding the total exposure of cVMS in the global environment.

Until now, there have been some literatures reporting cVMS in landfill gas and leachates in different countries, such as Germany, Sweden, Finland and Canada, etc. ${ }^{12-15}$ One study reported that the yearly average total VMS emission to air were 80 and $250 \mathrm{~kg} / \mathrm{y}$ respectively from two different landfills in Canada. ${ }^{16}$ However, due to limited samples $(n=1-3$ for each landfill) or short sampling periods ( $\sim$ two months), the seasonal variation of

\section{Received: July 16, 2017}

Revised: September 21, 2017

Accepted: September 27, 2017

Published: October 12, 2017 
either cVMS concentrations or mass loads were not analyzed in landfill gas and leachates through yearly cycle.

Another data gap is related to cVMS fate in landfill leachates. Before emission to aquatic environment, leachates are always treated on site or transferred to WWTPs. ${ }^{17}$ At present, the dominant leachate/wastewater treatment techniques are based on biological treatment processes, where main removal mechanisms of cVMS - volatilization and sorption to sludgehave been determined. ${ }^{5-9}$ However, before being transferred to treatment processes, leachates in most landfills are stored in opened storage pond, where long hydraulic retention time of the wastewater $\left(>24 \mathrm{~h} \sim 10 \mathrm{~s}\right.$ of days) ${ }^{18}$ and non-neutral (acidic or basic) $\mathrm{pH}$ of leachates may lead to significant removal (volatilization and hydrolysis) of cVMS. More important, landfill leachates often contain high concentrations of dissolve organic matter (DOM) and $\mathrm{NO}_{3}^{-17,19}$ - photosensitizers that could generate hydroxyl radicals $(\bullet \mathrm{OH})$ via photochemical reaction. $^{20-22}$ Furthermore, some acid landfill leachates contained high levels of transition metal ions ( such as $\mathrm{Fe}^{2+}$ ), ${ }^{23}$ which could accelerate $\bullet \mathrm{OH}$ production rates via photo-Fenton reaction with hydrogen peroxide (a common constituent of natural waterbody). ${ }^{24}$ As cVMS in air could be hydroxylated by $\bullet \mathrm{OH}^{25-27}$ the indirect phototransformation (hydroxylation) of cVMS in leachates of the storage pond may also be possible. To the best of our knowledge, up to now, there is no research on the fate of cVMS in leachate storage ponds of any landfills.

In the present study, based on a whole year sampling, occurrence of cVMS in biogas and leachates from one municipal landfill located in China was systematically investigated together with their removal in the coupled leachate storage pond. The main objectives of this study included: (1) to characterize seasonal trends of cVMS emission in landfill; (2) to test the hypothesis that cVMS could be hydroxylated by $\bullet \mathrm{OH}$ generated in situ in leachate storage pond; (3) to determine the further removal of hydroxylation products of cVMS in the leachate storage pond.

\section{MATERIALS AND METHODS}

2.1. Field Sample Collection. The studied municipal landfill, located in the east of Shandong Province, China, was opened at 2012, and processed approximately $220000 \mathrm{~kg} / \mathrm{d}$ of solid waste. The catchment area of the landfill covers about $171 \mathrm{~km}^{2}$, with a population of 300000 . In this landfill, the leachate from the drainage layer was pumped to one opened storage pond $\left(\right.$ square $=3000 \mathrm{~m}^{2}$, average leachate depth $=0.4 \mathrm{~m}$ ) with an average hydraulic retention time of $\sim 18$ days. Subsequently, the leachate in storage pond was pumped offsite for treatment at one municipal WWTP in the same catchment. Detailed information on seasonal change, physical and chemical characteristics of landfill matrices were provided in SI Table S1.

Thirty six sampling events were carried out from January to December 2016, that is, three events per month. In each event, $24 \mathrm{~h}$ composite influent leachate of the storage pond (i.e., the effluent of drainage layer) and coupled effluent leachate were collected using automatic samplers (with silicone-free tubing) at flow proportion mode, respectively. Before pretreatment, the leachate samples were stored in sealed glass tubes $(4 \mathrm{~L})$ without headspace at $4{ }^{\circ} \mathrm{C}$. Meanwhile, one $24 \mathrm{~h}$ air sample was collected from the exhaust gas pipe of the landfill by using a pump to pull air $(100 \mathrm{~L} / \mathrm{min})$ through one particle filter followed by precleaned PUF/XAD-2/PUF (10 g, Supelco) cartridge.
The breakthrough of cVMS was determined by mounting a backup cartridge in series with the primary cartridge.

At the same dates as landfill sampling (January to December 2016, three events per month), 24 h composite influent $(n=36)$ and effluent $(n=36)$ samples were also collected and stored form one municipal WWTP containing anaerobic-anoxic-oxic processes, which had same catchment with the landfill and treated the leachate effluents from the studied landfill. Notably, the influents of the WWTP were sampled at the site before leachate mixing, that is, leachate was not part of the influent sample of the WWTP.

Wind speeds and light intensities were measured on-site by TP6252A air velocity meter and HI97500 lux/light meter, respectively. Dissolved oxygen (DO), $\mathrm{pH}$ and electrical conductivity (EC) values of landfill leachates were determined by Hach HQ40d portable $\mathrm{DO} / \mathrm{pH} /$ conductivity multi-parameter meter. Dissolved organic carbons (DOC) of leachate were determined by TOC analyzer (TOC-VCPH, Shimadzu, Japan). $\mathrm{NO}^{3-}$ and total suspended solid (TSS) were monitored using standard methods for waters and wastewater analysis. ${ }^{28}$ Total nitrogen (TN) and $\mathrm{Fe}^{2+}$ were measured with persulfate and spectrophotometric methods, ${ }^{29,30}$ respectively.

2.2. Standards and Chemicals. Cyclic methylsiloxane standards (D4, D5, D6, purity >98\%) were purchased from Sigma-Aldrich (St. Louis, MO). ${ }^{13}$ C-labeled D4, D5, and D6 were purchase from Cambridge Isotope Laboratories (Andover, MA). 1-Hydroxy-nonamethylcyclopentasiloxane (D4TOH, purity $>95 \%)$ and 1-hydroxy-undecamethylcyclohexasiloxane (D5TOH, purity $>95 \%$ ) were custom-synthesized in Toronto Research Chemicals (Toronto, Ontario) and purified in Shandong University, China. Isopropanol, methanol, acetone, ethyl acetate, and $n$-hexane were purchased from Fisher Scientific (Fair Lawn, NJ).

2.3. Field Sample Pretreatment and Analysis. Aqueous Samples. Cyclic methylsiloxanes (D4, D5, D6) and hydroxylated methylsiloxanes (D4TOH, D5TOH) in aqueous samples were extracted by liquid-liquid extraction. ${ }^{13} \mathrm{C}-\mathrm{D} 4,{ }^{13} \mathrm{C}-\mathrm{D} 5$ and ${ }^{13} \mathrm{C}-\mathrm{D} 6$ were used as internal standards for D4, D5/D4TOH and D6/D5TOH, respectively. $100 \mathrm{~mL}$ of sample spiked with acetone solution of internal standards $(40 \mu \mathrm{L}, 500 \mu \mathrm{g} / \mathrm{L})$ was extracted with $25 \mathrm{~mL}$ of $n$-hexane followed by $20 \mathrm{~mL}$ of $n$-hexane/ethyl acetate (1:1 by volume). Subsequently, the organic layer was transferred to a flat-bottom flask and concentrated to $8-10 \mathrm{~mL}$ by evaporation at $30^{\circ} \mathrm{C}$ under a stream of nitrogen. The remaining extract was purified by passing through $1.0 \mathrm{~g}$ of anhydrous sodium sulfate cartridge, and then concentrated to $0.5 \mathrm{~mL}$ with the same way mentioned above, and diluted to $1 \mathrm{~mL}$ with $n$-hexane/ethyl acetate (1:1 by volume).

Air Samples. After sampling, the PUF/XAD-2/PUF sandwich was spiked with acetone solution of internal standards $(100 \mu \mathrm{L}$, $500 \mu \mathrm{g} / \mathrm{L},{ }^{13} \mathrm{C}-\mathrm{D} 4,{ }^{13} \mathrm{C}-\mathrm{D} 5$, and $\left.{ }^{13} \mathrm{C}-\mathrm{D} 6\right)$, and then extracted three times with $30 \mathrm{~mL}$ of ethyl acetate $n$-hexane mixture ( $1: 1$ by volume) by sonication for $1 \mathrm{~h}$. The total extract was concentrated to $1.0 \mathrm{~mL}$ with a gentle stream of nitrogen before analysis.

Full Scan analysis. Full scan chromatograms $(\mathrm{m} / \mathrm{z}$ range 50-600) for extracted compounds in leachate were analyzed by Agilent 7200 Q-TOF GC/MS, which was equipped with HP-5MS $30 \mathrm{~m} \times 0.25 \mathrm{~mm} \times 0.25 \mu \mathrm{m}$. Ion source temperature was $230^{\circ} \mathrm{C}$ for both electron-impact ionization (EI) and positive chemical ionization (PCI) mode. The EI and PCI mass spectra of $\mathrm{D} 4 \mathrm{TOH}$ and $\mathrm{D} 5 \mathrm{TOH}$, obtained by Q-TOF GC/MS, were described in SI Section 2. 
SIM Analysis. The concentrations of target compounds in leachate/air were acquired by selected ion monitoring (SIM) of GC-MS analysis using Agilent 7890A gas chromatograph -5975C mass spectrometric detector equipped with HP-5MS column $(30 \mathrm{~m} \times 0.25 \mathrm{~mm} \times 0.25 \mu \mathrm{m})$. The MS was operated in electronimpact ionization mode (EI) at $70 \mathrm{eV}$, ion source temperature of $230{ }^{\circ} \mathrm{C}$ and quadrupole temperature of $150^{\circ} \mathrm{C}$. MS parameters for compounds were summarized in SI Table S2.

2.4. Quality Assurance/Quality Control (QA/QC). Similar to our previous studies, ${ }^{31,32}$ we made some efforts to reduce siloxanes contamination during sample collection and analysis. First, the analyst did not use consumer products containing siloxanes. Second, prior to use, all glass tubes were cleaned with hexane, and then heated at $300{ }^{\circ} \mathrm{C}$ for $10 \mathrm{~h}$. Third, prior to use, both anhydrous sodium sulfate and PUF/XAD-2/PUF cartridges were immersed in hexane for $4 \mathrm{~h}$, and subsequently rinsed with $10 \mathrm{~mL}$ of hexane. After rinsing, the cartridges were dried using purified nitrogen and stored in capped glass tubes. Fourth, only steel pipes, but not silicone pipes, were used for nitrogen blow process. Fifth, all field blanks were collected to assess potential ambient contamination-the field blanks of air were collected by exposing PUF/XAD-2/PUF cartridges for $1 \mathrm{~min}$ at the sampling site, while the aqueous field blanks (leachate and wastewater) were prepared with a water solution of siloxane-free commercial humic acid (Sigma-Aldrich, St. Louis, MO). Finally, for every five air or aqueous samples, a procedural blank was prepared and analyzed.

$\mathrm{D} 4 \mathrm{TOH}$ and $\mathrm{D} 5 \mathrm{OH}$ were not found in any field or procedural blanks of the aqueous samples. Their limits of quantitation (LOQs), determined as 10 times the standard deviation of signals of procedural blank samples $(n=7)$ spiked with target compounds (100 ng/L), were $4.5-7.5 \mathrm{ng} / \mathrm{L}$ in aqueous sample (SI Table S3). Recoveries of D4TOH and D5TOH in aqueous samples were $88-94 \%$ (SI Table S3).

Mean concentrations of D4, D5 and D6 were $1.2-3.9 \mathrm{ng} / \mathrm{L}$ in aqueous field blanks, and $0.9-3.2 \mathrm{ng} / \mathrm{m}^{3}$ in air field blanks, $0.6-2.4 \mathrm{ng} / \mathrm{L}$ in aqueous procedural blanks and $0.3-2.2 \mathrm{ng} / \mathrm{m}^{3}$ in air procedural blanks, respectively (SI Table S3). LOQs for D4-D6, determined as 10 times the standard deviation of the procedural blank signals $(n=7)$, were $1.7-2.8 \mathrm{ng} / \mathrm{L}$ in aqueous samples, while $2.2-4.5 \mathrm{ng} / \mathrm{m}^{3}$ in air samples. Recoveries of cVMS in aqueous and air samples were $88-94 \%$ and $83-94 \%$, respectively (SI Table S3). All reported concentrations of D4, D5 and D6 in this study were reported with their field blank values subtracted.

2.5. Simulated Experiments. 2.5.1. Elimination of Methylsiloxanes in Leachate. As all effluent leachates of storage pond contained high levels (>100 ng/L, SI Table S4) of D5 and D6, their standard solutions were not added in leachates during this experiment. However, $40 \mu \mathrm{L}$ of acetone solution of D4 $(1.00 \mathrm{mg} / \mathrm{L})$ were added into 24 samples (collected during April 6 to November 29) due to its low original concentrations $(<\mathrm{LOD}-95.7 \mathrm{ng} / \mathrm{L})$. For each of effluent leachate samples $(n=36)$ collected from the storage pond during 12 months, one set of 15 opened glass vials $(40 \mathrm{~mL})$ containing $40 \mathrm{~mL}$ of leachate were incubated under the similar illumination intensity, wind speed and air/leachate temperature as the corresponding values measured when the effluent leachate sample was collected (SI Table S1). The light source was solar simulator with $500 \mathrm{~W}$ xenon Lamps, and simulated illumination intensities were obtained by adjusting electric current of light source. At each of the predetermined time intervals $(0,2,10,24$, and 48 days), three vials were taken to determine concentrations of D4, D5, and D6.
Meanwhile, two additional sets of 15 glass vials - one capped and another open set - were also incubated under the same conditions except they were not illuminated. Furthermore, for evaluating methylsiloxanes hydroxylation arose from hydroxyl radical, the fourth set, opened under illumination and spiked with $100 \mu \mathrm{g} / \mathrm{L}$ of isopropanol as $\bullet \mathrm{OH}$ scavenger ${ }^{33}$ was prepared for each of the three leachate effluents collected during June. Meanwhile, the full scan chromatograms for transformation products of D5 and D6 in leachates under illumination were analyzed by Agilent 7200 Q-TOF GC/MS with method mentioned in Section 2.3.

2.5.2. Phototransformation of D5 and D6 in Aqueous Environment. Aqueous samples for phototransformation experiments were prepared by diluting the stock solution of DOM (DOC $=10.0 \mathrm{~g} / \mathrm{L})$, which was concentrated from the leachate effluent of the studied storage pond (as described in the SI), with Milli-Q ultrapure water. Since dissolved oxygen - the important participating substance for DOM photochemical reaction ${ }^{20,21}$ may be reduced with the increase of incubation time in capped leachate systems, the phototransformation experiments of D5 and D6 were performed in opened systems. Aqueous samples $(40 \mathrm{~mL})$, with different levels of DOM $(\mathrm{DOC}=0-1000 \mathrm{mg} / \mathrm{L}$, $\left.\mathrm{pH} 7.0, \mathrm{NO}^{3-}=0, \mathrm{Fe}^{2+}=0\right), \mathrm{NO}_{3}^{-}\left(0-2000 \mathrm{mg} / \mathrm{L}, \mathrm{NaNO}_{3}\right.$, $\left.\mathrm{DOC}=1000 \mathrm{mg} / \mathrm{L}, \mathrm{pH} \mathrm{7.0}, \mathrm{Fe}^{2+}=0\right)$ and $\mathrm{Fe}^{2+}(0-2000 \mathrm{mg} / \mathrm{L}$, $\left.\mathrm{FeSO}_{4}, \mathrm{DOC}=1000 \mathrm{mg} / \mathrm{L}, \mathrm{NO}^{3-}=0, \mathrm{pH} 7.0\right)$, were spiked with acetone solution $(40 \mu \mathrm{L}, 500 \mu \mathrm{g} / \mathrm{L})$ of D5 and D6, respectively, and then incubated in 15 opened glass vials under different light intensities $(0-80000 \mathrm{~lx})$. At each of the predetermined time intervals $(0,2,10,24$, and 48 days $)$, three vials were taken to determine concentrations of D5 and D6. To subtract volatilization and hydrolysis rates of D5 and D6, another paired set of 15 opened glass vials were incubated under nonillumination.

2.5.3. Elimination of Hydroxylated Methylsiloxanes (D4TOH and D5TOH) in Leachates. The stock solution of DOM (Section 2.5.2), spiked with $\mathrm{FeSO}_{4}$ and $\mathrm{NaNO}_{3}$, was diluted to simulate leachates $(\mathrm{DOC}=2000 \mathrm{mg} / \mathrm{L}$, temperature $=$ $21.0{ }^{\circ} \mathrm{C}, \mathrm{pH} \quad 6.5, \quad \mathrm{Fe}^{2+}=2000 \mathrm{mg} / \mathrm{L}, \mathrm{NO}_{3}{ }^{-}=1400 \mathrm{mg} / \mathrm{L}$ ) collected from effluent of the storage pond in June, when fastest productions of $\mathrm{D} 4 \mathrm{TOH}$ and D5TOH were found, as discussed in Section 3.2.

For D4TOH and D5TOH, four sets of 15 glass vials $(40 \mathrm{~mL})$ one set opened under illumination (light intensity $=65000 \mathrm{~lx}$ ), one set opened under nonillumination, one set capped under nonillumination, and one set (sterilized by $1 \% \mathrm{NaN}_{3}$ ) capped under nonillumination - were filled with simulated leachate $(40 \mathrm{~mL})$ and acetone solutions of hydroxylated methylsiloxane $(100 \mu \mathrm{L}, 200 \mu \mathrm{g} / \mathrm{L})$, respectively. For each set of glass vials $(n=15)$, three vials were sacrificed for the determination of the remaining cVMS concentrations at each of the predetermined time intervals $(0,2,10,24$, and 48 days $)$. Meanwhile, in set capped under nonillumination, dimethylsilanediol $\left[\mathrm{Me}_{2} \mathrm{Si}(\mathrm{OH})_{2}\right]$ and methylsilanetriol $\left[\mathrm{MeSi}(\mathrm{OH})_{3}\right]$ were also analyzed with methods described in the SI.

\section{RESULTS AND DISCUSSION}

3.1. Methylsiloxanes in Landfill Gas and Influent Leachate. Occurrence. D4, D5 and D6 were detected in all influent samples $(n=36)$ of storage pond collected in 2016, with concentrations ranging from 0.338 to $7.18 \mu \mathrm{g} / \mathrm{L}, 4.23-30.5 \mu \mathrm{g} / \mathrm{L}$, and $1.00-14.7 \mu \mathrm{g} / \mathrm{L}$, respectively (SI Table S4), which were similar to their reported concentrations in leachates from landfills 
located in Sweden $(1-2 \mu \mathrm{g} / \mathrm{L}$ for D4, 0.1-0.4 $\mu \mathrm{g} / \mathrm{L}$ for D5) and Finland $\left(3.9 \mu \mathrm{g} / \mathrm{L}\right.$ for D5, $1.7 \mu \mathrm{g} / \mathrm{L}$ for D6). ${ }^{12}$

In all landfill gas samples $(n=36)$, D4 $\left(0.753-2.33 \mathrm{mg} / \mathrm{m}^{3}\right)$ and D5 $\left(0.105-0.738 \mathrm{mg} / \mathrm{m}^{3}\right)$ were detected, while D6 concentrations were all below detection limits. D4 and D5 concentration in biogas were similar to those in biogas samples from Canada $\left(1.27-5.03 \mathrm{mg} / \mathrm{m}^{3}\right.$ for D4 and $0.395-3.33 \mathrm{mg} / \mathrm{m}^{3}$ for D5) and Germany $\left(4.24-8.84 \mathrm{mg} / \mathrm{m}^{3}\right.$ for $\mathrm{D} 4$ and $0.4-1.09 \mathrm{mg} / \mathrm{m}^{3}$ for D5), etc. ${ }^{14,15}$

Mass Load to the Local Environment. The annual mass load of cVMS in leachate/biogas was calculated using the following equation:

$$
\begin{aligned}
M= & \sum_{i=1}^{12}\left\{\left[C_{\mathrm{i}(1)} \times V_{\mathrm{i}(1)}+C_{\mathrm{i}(2)} \times V_{\mathrm{i}(2)}+C_{\mathrm{i}(3)} \times V_{\mathrm{i}(3)}\right] / 3\right\} \\
& \times \mathrm{d}_{\mathrm{i}}
\end{aligned}
$$

Where $i$ represented number $(1-12)$ of sampling month; $C_{\mathrm{i}(1)}-C_{\mathrm{i}(3)}$ represented the concentrations of target compounds in three leachate/biogas samples from the i month; $V_{\mathrm{i}(1)}-V_{\mathrm{i}(3)}$ represents the daily volume rates of leachate/biogas during three sampling events in the i month; $d_{i}$ represents the total days of the i month. It was too difficult to collect leachate/biogas samples in all days $(n=366)$ of the tested year, and the sampling times in the present study were relatively limited - 3 days for each month. Therefore, there may be some deviations between our estimated annual mass loads of cVMS and the actual values.

Totally, the annual mass loads were about $84.5 \mathrm{~g}$ for D4, $435 \mathrm{~g}$ for D5, and $160 \mathrm{~g}$ for D6 in influent of storage pond, an they were $664 \mathrm{~g}$ for D4 and $155 \mathrm{~g}$ for D5 in biogas, respectively. Through dividing their total mass loads in leachate and biogas by served population (300 000) of the landfill, the calculated annual emission to landfill (leachate+biogas) per capita was $2.50 \mathrm{mg}$ for D4, $1.97 \mathrm{mg}$ for D5 and $0.533 \mathrm{mg}$ for D6, respectively.

For the total environment of any urban locations, cVMS may also be released to WWTP. cVMS in municipal WWTPs were mainly attributed to their residuals in cosmetics, personal care and household products used by general public, while $90 \%$ of which may already volatilized to the air compartment before they reach the wastewater stream. ${ }^{1-3}$ For the study location, we detected cVMS concentrations of $0.164-0.353 \mu \mathrm{g} / \mathrm{L}$ for D4, 1.33-2.90 $\mu \mathrm{g} / \mathrm{L}$ for D5, and $0.412-0.941 \mu \mathrm{g} / \mathrm{L}$ for D6 (SI Table S5) in influents of one municipal wastewater treatment plant having the same catchment with the studied landfill. Their annual mass loads per capita through the influents to the WWTP were $10.5 \mathrm{mg}$ for D4, $84.5 \mathrm{mg}$ for D5, $26.4 \mathrm{mg}$ for D6. Therefore, we roughly estimated that annual total emission rates (to air before reaching WWTP and influent wastewater of WWTP) of D4, D5, and D6 per capita through using cosmetics, personal care and household products in the studied area were $105 \mathrm{mg}$ for D4, $845 \mathrm{mg}$ for D5 and $264 \mathrm{mg}$ for D6, respectivelyabout 31-362 times larger than emission rates of cVMS from solid siloxane-containing wastes disposal.

Temporal Trend. Figure 1 showed that at 2016, the mass load of $\sum \mathrm{D} 4-\mathrm{D} 6 \mathrm{had}$ increasing trends both in leachates (from 1234 to $5760 \mathrm{mg} / \mathrm{d}$ ) and biogas (from 591 to $6575 \mathrm{mg} / \mathrm{d}$ ) from January to July (Summer), while decreasing trends both in leachates (from 5760 to $659 \mathrm{mg} / \mathrm{d}$ ) and biogas (from 6575 to $680 \mathrm{mg} / \mathrm{d}$ ) during July-December (Winter). Logarithm of emission rates of cVMS in both biogas and leachates had statistical correlations with several characteristics of influent leachate and air (SI Table S6), such as DOC, air/leachate temperature, $\mathrm{EC}, \mathrm{NO}_{3}{ }^{-}$, etc. However, kinds of characteristics had bivariate correlations (SI Table S6), and their principal components analysis was not suitable, cumulative percentage of variance explained by components with eigenvalues $>1$ were limited (74.65\%, SI Table S7). Therefore, it was too difficult to comprehensively discuss influence of all kinds of leachate characteristics on cVMS emission rates. In this section, we merely evaluated influences of temperature and DOC on cVMS emission.

Due to seasonal change, air and leachate temperatures increased from -3.4 to $35^{\circ} \mathrm{C}$ and from 5.43 to $28.9^{\circ} \mathrm{C}$ during January to July, respectively, while decreased from 35 to $2.3^{\circ} \mathrm{C}$ and from 28.9 to $5.02{ }^{\circ} \mathrm{C}$ during July-December, respectively. High temperatures should accelerate desorption rates of cVMS from solid waste. ${ }^{1-3}$ In the present study, the logarithm of mass load of D4 (slope $=-2802, R^{2}=0.855, p<0.05$ ) and D5 (slope $=-3343, R^{2}=0.7184, p<0.05$ ) in biogas had inversely relations with reciprocal of leachate temperatures (SI Figure S1). Meanwhile, higher leachate temperature would accelerate anaerobic degradation, which turn the solid organic matter with high molecular weight into DOC with low molecular weight. $^{34}$ Logarithm of DOC mass load in influent leachates had inversely relations (slope $=-1957, R^{2}=0.6754, p<0.05$, SI Figure S2) with reciprocal of leachate temperatures. Dissolved organic matter also could elevate the release of methylsiloxanes from solid phase. ${ }^{35}$ In the present study, the logarithm of mass load of cVMS in both biogas and leachate had positive relations (slope $\left.=0.0004-0.0008, R^{2}=0.5138-0.841, p<0.05\right)$ with DOC concentrations (SI Figure S3).

3.2. Time Trends of Methylsiloxanes Elimination in the Leachate Storage Pond. Concentrations of cVMS were $3.21-459 \mathrm{ng} / \mathrm{L}$ for D4 [detection frequencies $(\mathrm{df})=83.3 \%$ ], $0.121-5.97 \mu \mathrm{g} / \mathrm{L}$ for D5 $(\mathrm{df}=100 \%)$ and $0.474-4.47 \mu \mathrm{g} / \mathrm{L}$ for D6 $(\mathrm{df}=100 \%)$ in effluents of leachate storage pond, while $3.67-11.6 \mathrm{ng} / \mathrm{L}$ for D4 ( $\mathrm{df}=100 \%), 55.9-133 \mathrm{ng} / \mathrm{L}$ for D5 $(\mathrm{df}=100 \%)$, and $12.3-38.1 \mathrm{ng} / \mathrm{L}$ for $\mathrm{D} 6(\mathrm{df}=100 \%)$ in effluents of the studied WWTP, respectively (SI Table S4 and S5).

The removal efficiencies of cVMS in storage pond $\left(\mathrm{RE}_{\mathrm{RP}}\right)$ and WWTP $\left(\mathrm{RE}_{\text {WWTP }}\right)$ were calculated with the following equations:

$$
\begin{aligned}
\mathrm{RE}_{\mathrm{RP}}= & 100 \% \times\left(M_{\text {inf-RP }}-M_{\text {eff-RP }}\right) / M_{\text {inf-RP }} \\
\mathrm{RE}_{\mathrm{WWTP}}= & 100 \% \times\left(M_{\text {eff-RP }}+M_{\text {inf-WWTP }}-M_{\text {eff-WWTP }}\right) \\
& /\left(M_{\text {eff-RP }}+M_{\text {inf-WWTP }}\right)
\end{aligned}
$$

Where $M_{\text {inf-RP }}$ and $M_{\text {eff-RP }}$ represent mass load of cVMS in influent and effluent of storage pond, whereas $M_{\text {inf-WwTP }}$ and $M_{\text {eff-WWTP }}$ represent mass load of cVMS in influent and effluent of WWTP, respectively.

Generally, removal efficiencies (SI Table S8) were for 81.1-100\% $($ mean $=94.9 \%)$ for D4, 57.1-98.1\% (mean $=73.3 \%)$ for D5 and $35.4-73.7 \%$ (mean $=53.2 \%$ ) for D6 in leachate storage pond, while 96.3-98.1\% (mean $=97.5 \%$ ) for D4, 95.7-97.0\% (mean $=95.9 \%)$ for D5 and 95.7-97.4\% (mean = 96.6\%) for D6 in the WWTP, respectively. As previous literatures had determined the main removal mechanisms of cVMS in WWTPs-volatilization and sorption to sludge, ${ }^{5-9}$ the main focus of the present study is the cVMS removal in leachate storage pond as discussed in the following paragraphs.

In storage pond, the most significant removals of $\mathrm{D} 4\left(\mathrm{RE}_{\mathrm{RP}}=\right.$ $99.8-100 \%, 99.9 \%$ at mean $)$ and $\mathrm{D} 5\left(\mathrm{RE}_{\mathrm{RP}}=94.5-98.1 \%\right.$, 96.2\% at mean) were found in August, while D6 was fastest removed $\left(\mathrm{RE}_{\mathrm{RP}}=65.2-73.7 \%, 70.0 \%\right.$ at mean $)$ in June (Figure 1, SI Table S8). Based on incubating all effluent leachate 

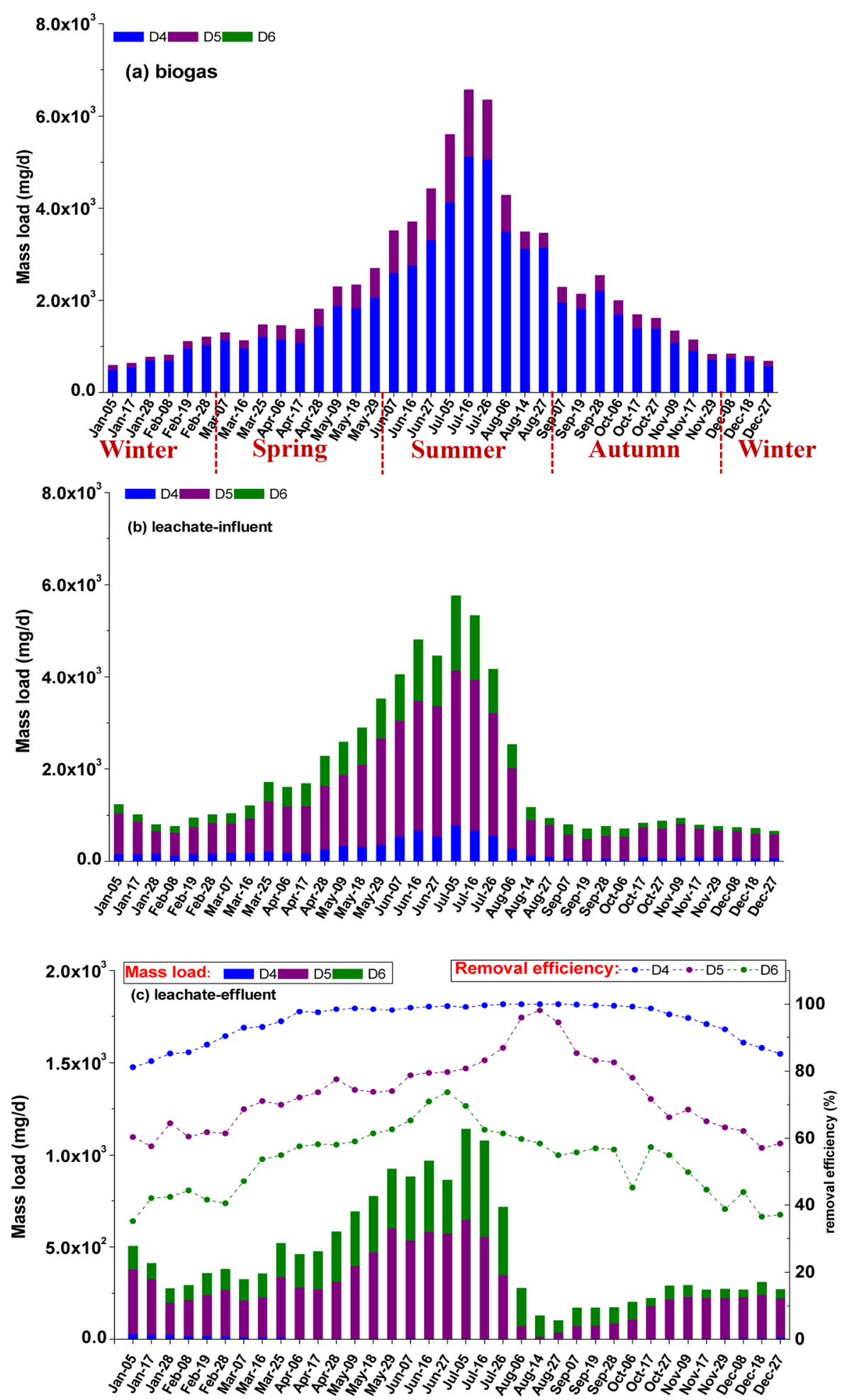

Figure 1. mass loads of cVMS in biogas/leachate, and their removal efficiencies in leachate storage pond.

samples $(n=36)$ collected from storage pond in the whole year under various conditions (e.g., capped or opened; illumination or nonillumination), we made semilog plots of cVMS concentrations versus incubation time (SI Figure S4), and then calculated their first-order rates of volatilization, hydrolysis, and phototransformation in these leachates: (1) hydrolysis rates of cVMS were their slopes of semilog plots in capped system under nonillumination; (2) volatilization rates were calculated by subtracting the slopes of semilog plots in the capped system under nonillumination from the values in paired opened system under nonillumination; (3) phototransformation rates were calculated by subtracting the slopes of semilog plots in the opened system under nonillumination from the values in paired opened system under illumination.

D4. Overall, hydrolysis $\left(k=3.34 \times 10^{-2} \mathrm{~d}^{-1}\right.$ at mean $)$ was the predominant removal mechanism for $\mathrm{D} 4$ in the whole year, followed by volatilization $\left(k=2.93 \times 10^{-2} \mathrm{~d}^{-1}\right.$ at mean $)$. Degradation rates of D4 in leachate under nonillumination were 
approximately equal to those under illumination, indicating its poor in-/directed phototransformation of D4. Higher air temperature $\left(33.3^{\circ} \mathrm{C}\right.$ at mean $)$ in August perhaps lead to larger usage of alkaline domestic products (such as soaps, body washes and detergent, etc) in the studied area, which may explain the higher $\mathrm{pH}($ mean $=8.0)$ of leachates in this month than those $\mathrm{pH}$ values $(6.3-7.8$, mean $=7.2)$ for the rest of the year. Hydrolysis rates $\left(k=4.43 \times 10^{-2}-1.88 \times 10^{-1} \mathrm{~d}^{-1}\right)$ of D4 during July 26 to September 7, especially in August $\left(k=1.04 \times 10^{-1}-1.88 \times\right.$ $\left.10^{-1} \mathrm{~d}^{-1}\right)$, were faster than those $\left(k=9.71 \times 10^{-3}-3.67 \times\right.$ $10^{-2} \mathrm{~d}^{-1}$ ) in the rest of the year (Figure 2), perhaps because of both high leachate $\mathrm{pH}(7.6-8.1)$ and temperature $\left(24.0-28.5^{\circ} \mathrm{C}\right.$, mean $=26.7^{\circ} \mathrm{C}$ ) in this period. As leachate $\mathrm{pH}$ increased from 7.6 to 8.1 , the hydrolysis rates of D4 increased 4.3 times, which was in the same order of magnitude as the calculated value (3.2 times) based on the reported acid- $\left(k=3.91 \times 10^{3}\right.$ at $\left.25^{\circ} \mathrm{C}\right)$ and base- $\left(k=7.10 \times 10^{4}\right.$ at $\left.25{ }^{\circ} \mathrm{C}\right)$ catalyzed reaction rate constants of D4. ${ }^{1}$ In addition, volatilization rates of D4 in August $\left(k=5.78 \times 10^{-2}-6.78 \times 10^{-2} \mathrm{~d}^{-1}\right.$, that is, $t_{1 / 2}=4.44-5.21$ days $)$ were also faster than those in other months $(k=1.20 \times$ $10^{-2}-5.25 \times 10^{-2} \mathrm{~d}^{-1}$, that is, $t_{1 / 2}=5.73-25.0$ days $)$, which should be attributed to higher air/leachate temperature in this month- the logarithm of volatilization rates of cVMS had inversely relations (slope $=-1949 \sim-481, R^{2}=0.7092-0.8814$, $p<0.05$ ) with reciprocal of leachate temperatures (SI Figure S5).

D5. Different from D4, volatilization $\left(k=1.18 \times 10^{-2} \mathrm{~d}^{-1}\right.$ at mean) was the predominant removal mechanism for D5, followed by hydrolysis $\left(k=5.95 \times 10^{-3} \mathrm{~d}^{-1}\right.$ at mean $)$. Although phototransformation of D5 $\left(k=5.38 \times 10^{-4}-3.34 \times 10^{-3} \mathrm{~d}^{-1}\right.$, mean $\left.=1.38 \times 10^{-3} \mathrm{~d}^{-1}\right)$ was more apparent than those of D4, these phototransformation rates were approximately 1 order of magnitude lower than paired volatilization and hydrolysis rates. Similar to D4, D5 had the fastest volatilization $(k=2.01 \times$ $10^{-2}-2.51 \times 10^{-2} \mathrm{~d}^{-1}$, that is, $t_{1 / 2}=12.0-15.0$ days $)$ and hydrolysis $\left(k=1.58 \times 10^{-2}-3.34 \times 10^{-2} \mathrm{~d}^{-1}\right.$, that is, $t_{1 / 2}=$ 9.00-19.0 days) in August (Figure 2), meaning that highest $\mathrm{RE}_{\mathrm{RP}}$ of D5 found in August should also arise from its fastest volatilization and hydrolysis.

D6. The highest volatilization $\left(k=2.81 \times 10^{-3}-2.84 \times 10^{-3}\right.$ $\mathrm{d}^{-1}$, that is, $t_{1 / 2}=106-107$ days $)$ and hydrolysis $\left(k=2.66 \times 10^{-3}-\right.$ $3.79 \times 10^{-3} \mathrm{~d}^{-1}$, that is, $t_{1 / 2}=79.5-113$ days $)$ rates of D6 were also found in August (Figure 2). However, different from those of D4 and D5, phototransformation of D6 had a significant larger contribution (50.0-75.5\%) to its total removal in leachate than volatilization (15.8-31.6\%) and hydrolysis (7.59-35.3\%) during the whole year. The fastest phototransformation of D6 $\left(k=1.00 \times 10^{-2}-1.18 \times 10^{-2} \mathrm{~d}^{-1}\right.$, that is, $t_{1 / 2}=25.5-30.0$ days $)$ was found in June, which could explain why the biggest $\mathrm{RE}_{\mathrm{RP}}$ of D6 in the storage pond were found in this month.

Hydroxylation of cVMS in Leachate. As methylsiloxanes could not undergo direct photolysis, ${ }^{1-3}$ phototransformation of D5 and D6 in leachates should be attributed to their reaction with other photoproducts. By subtracting the slopes of semilog plots (SI Figure S6) in the opened system under nonillumination from the values in paired opened system under illumination spiked with/without hydroxyl scavenger (isopropanol), we found that phototransformation rates of D5 $\left(k=2.42 \times 10^{-4} \mathrm{~d}^{-1}\right.$ at mean $)$ and D6 $\left(k=6.96 \times 10^{-4} \mathrm{~d}^{-1}\right.$ at mean $)$ in three leachate effluents collected during June spiked with hydroxyl scavenger (isopropanol) were 13 and 16 times lower than those of D5 ( $k=$ $3.18 \times 10^{-3} \mathrm{~d}^{-1}$ at mean $)$ and D6 $\left(k=1.10 \times 10^{-2} \mathrm{~d}^{-1}\right.$ at mean $)$ in paired isopropanol-free samples, respectively. These results indicated compared with other photoinduced radicals (such as superoxide anion radical and singlet oxygen, etc), $\mathrm{OH}$ radicals may play a dominant role in phototransformation of cVMS. The above speculation was further proved by the detection of $\mathrm{D} 4 \mathrm{TOH}$ and $\mathrm{D} 5 \mathrm{TOH}$ - typical hydroxylation products of D5 and $\mathrm{D} 6$ by $\mathrm{OH}$ radicals, respectively-in EI and PCI full scan chromatograms for leachates under illumination (SI Figure S7).

Through principal component analysis followed by multiple linear regression (SI Table S9-S13), we found that $\mathrm{NO}_{3}{ }^{-}$mean standard coefficient $(\mathrm{SC})=0.23]$, DOC (mean SC $=0.20), \mathrm{Fe}^{2+}$ (mean SC $=0.20)$, and light intensity $(\mathrm{SC}=0.19$ at average) have more apparent influence on phototransformation rates of D5 and D6 than other leachate characteristics. In detail, the fastest phototransformation of D5 and D6 in leachate effluents of storage pond in June may be caused by the following reasons. First, $\mathrm{OH}$ radicals in aqueous environment should be mainly attributed to the photochemical reaction of dissolved organic matter and $\mathrm{NO}_{3}{ }^{-}$, both of which had higher concentrations $\left(\right.$ mean $=1733 \mathrm{mg} / \mathrm{L}$ for DOM, mean $=1412 \mathrm{mg} / \mathrm{L}$ for $\left.\mathrm{NO}_{3}{ }^{-}\right)$in June than those in other months $(1125 \mathrm{mg} / \mathrm{L}$ for DOM, $797 \mathrm{mg} / \mathrm{L}$ for $\mathrm{NO}_{3}{ }^{-}$, mean value), perhaps because high leachate temperature $\left(\right.$ mean $\left.=21.2{ }^{\circ} \mathrm{C}\right)$ in June would elevate both anaerobic degradation of solid organic matter to dissolved organic matter and nitrification of ammonia nitrogen to $\mathrm{NO}_{3}{ }^{-36}$ Notably, although temperatures $\left(\right.$ mean $\left.=26.3^{\circ} \mathrm{C}\right)$ of leachate effluents in July and August were higher than those (mean = $\left.21.2^{\circ} \mathrm{C}\right)$ in June, $\mathrm{DOM}($ mean $=1256 \mathrm{mg} / \mathrm{L})$ and $\mathrm{NO}_{3}{ }^{-}($mean $=$ $934 \mathrm{mg} / \mathrm{L}$ ) concentrations in these two months were lower than those in June (Table S1), perhaps because anaerobic degradation (optimum $\mathrm{pH}=6.5-7.2$ ) of organic compounds may be retarded in the alkaline leachates ( $\mathrm{pH} 7.7$ at mean) in the latter two months. ${ }^{37}$ Second, faster anaerobic degradation of solid organic matter may produce dissolved organic matter (including organic acids) in June and reduced leachate $\mathrm{pH}(\mathrm{pH}$ 6.3-6.6), which, in turn, may lead to $\mathrm{Fe}^{2+}$ accumulate in leachate, $\mathrm{Fe}^{2+}$ concentrations $($ mean $=1976 \mathrm{mg} / \mathrm{L})$ in June were higher than those in other months (mean $=670 \mathrm{mg} / \mathrm{L}$ ). Reduced Fe ions $\left(\mathrm{Fe}^{2+}\right)$ also could accelerate the photoproduction of hydroxyl radicals by reacting with $\mathrm{H}_{2} \mathrm{O}_{2}$, another photoproducts of DOM. $^{38}$ Third, light intensities (mean $=686$, unit: $100 \mathrm{~lx}$ ) were highest in June in the studied area $\left(36.58^{\circ} \mathrm{N}, 120.42^{\circ} \mathrm{E}\right)$, which could accelerate photoreaction of DOM and $\mathrm{NO}^{3-}$ to $\mathrm{OH}$ radicals.

Phototransformation of cVMS in Simulated Leachate. To further test our speculation about factors accelerating methylsiloxanes phototransformation in leachate, we investigated the influences of $\mathrm{DOM}, \mathrm{NO}_{3}{ }^{-}, \mathrm{Fe}^{2+}$ and light intensities on hydroxylation rates of D5 and D6 through illumination experiments (Figure 3). As DOM concentrations increased from 10 to $200 \mathrm{mg} / \mathrm{L}$, elimination rates of D5 and D6 in leachate increased 3.8 and 4.4 times, while decreased 1.5 times and 1.5 times as DOM increasing from 200 to $1000 \mathrm{mg} / \mathrm{L}$, respectively, perhaps because $\bullet \mathrm{OH}$-scavenging rates of $\mathrm{DOM}^{39}$ with too high concentrations would be faster than its $\bullet \mathrm{OH}$ generation. This result indicated that faster phototransformation of D5 and D6 in June should not be mainly attributed to high DOM concentrations $($ mean $=1733 \mathrm{mg} / \mathrm{L}$ ) in this month. Logarithms of elimination rate constants for both D5 and D6 were positively related to the logarithms of $\mathrm{NO}_{3}{ }^{-}$(the slope $=$ 0.062 for D5 and 0.064 for D6), $\mathrm{Fe}^{2+}$ (the slope $=0.0779$ for D5 and 0.0816 for D6) and light intensity (the slope $=0.2414$ for D5 and 0.3616 for D6), indicating that their faster phototransformation rates in June may arose from higher concentrations of $\mathrm{NO}_{3}$ - and $\mathrm{Fe}^{2+}$ and light intensities in this month. 


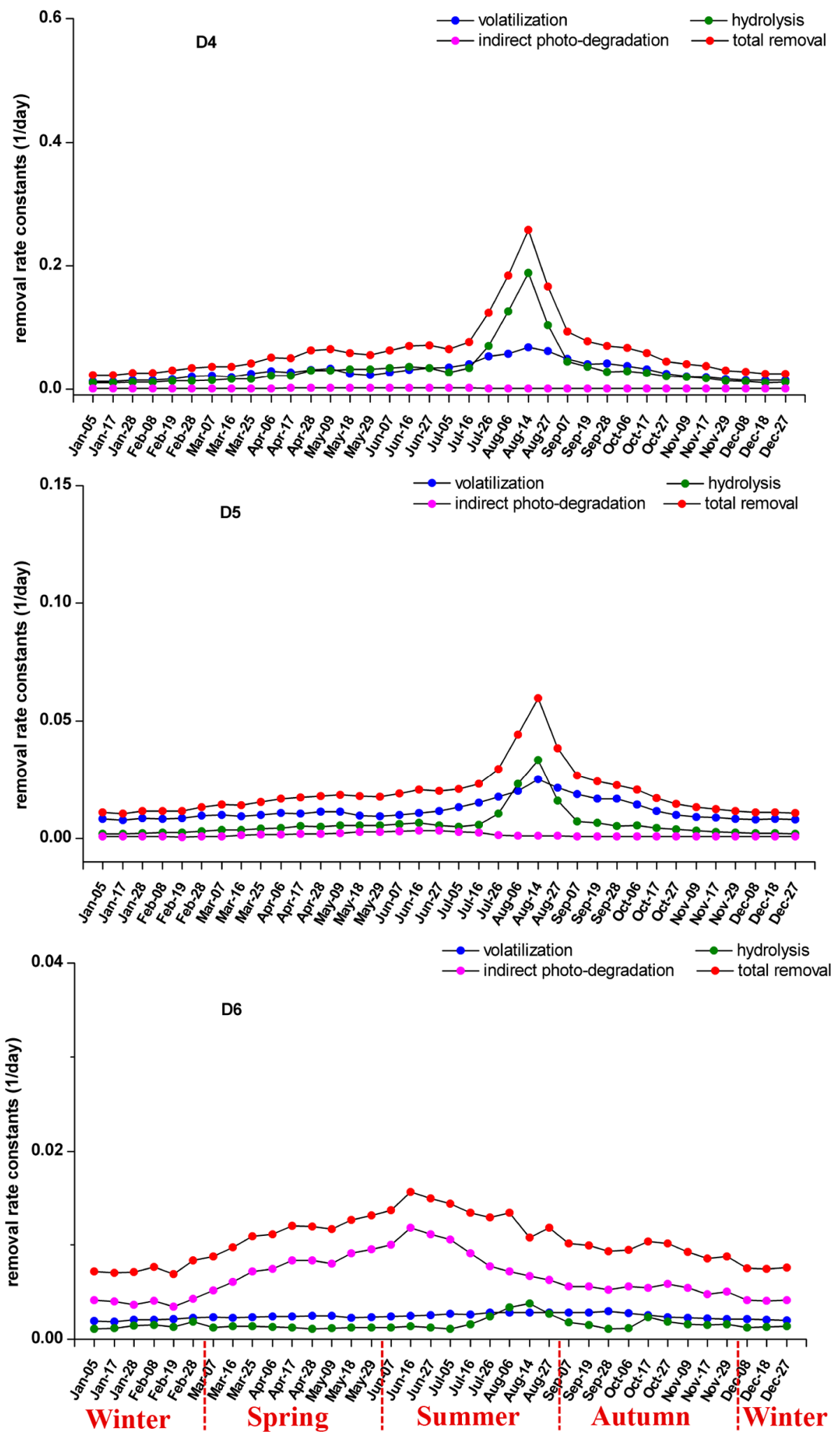

Figure 2. Temporal trends of removal rate constants of cVMS in leachate storage pond.

3.3. Simulated Experiments for Further Elimination of Hydroxylation Products of Methylsiloxanes in Leachate. Section 3.2 showed that D5 and D6 in leachates could undergo hydroxylation to $\mathrm{D} 4 \mathrm{TOH}$ and $\mathrm{D} 5 \mathrm{TOH}$, respectively. Overall, $\mathrm{D} 4 \mathrm{TOH}$ and $\mathrm{D} 5 \mathrm{TOH}$ were not detected in any leachate influent samples, but detected in six leachate effluents collected during May-July, with concentrations in the ranges of 39.6-58.2 ng/L and 104-187 ng/L, respectively (SI Table S4). Based on their phototransformation rates in leachates during May-June (Figure 2) and hydraulic retention time of storage pond (18 days), we estimated that Si mass ratios of phototransformation products of D5 and D6 to their paired cVMS should be 10.6-15.0\% $($ mean $=13.1 \%)$ and $55.1-82.4 \%($ mean $=66.8 \%)$, respectively, which were 13-19 times larger than Si mass ratios of D4TOH 

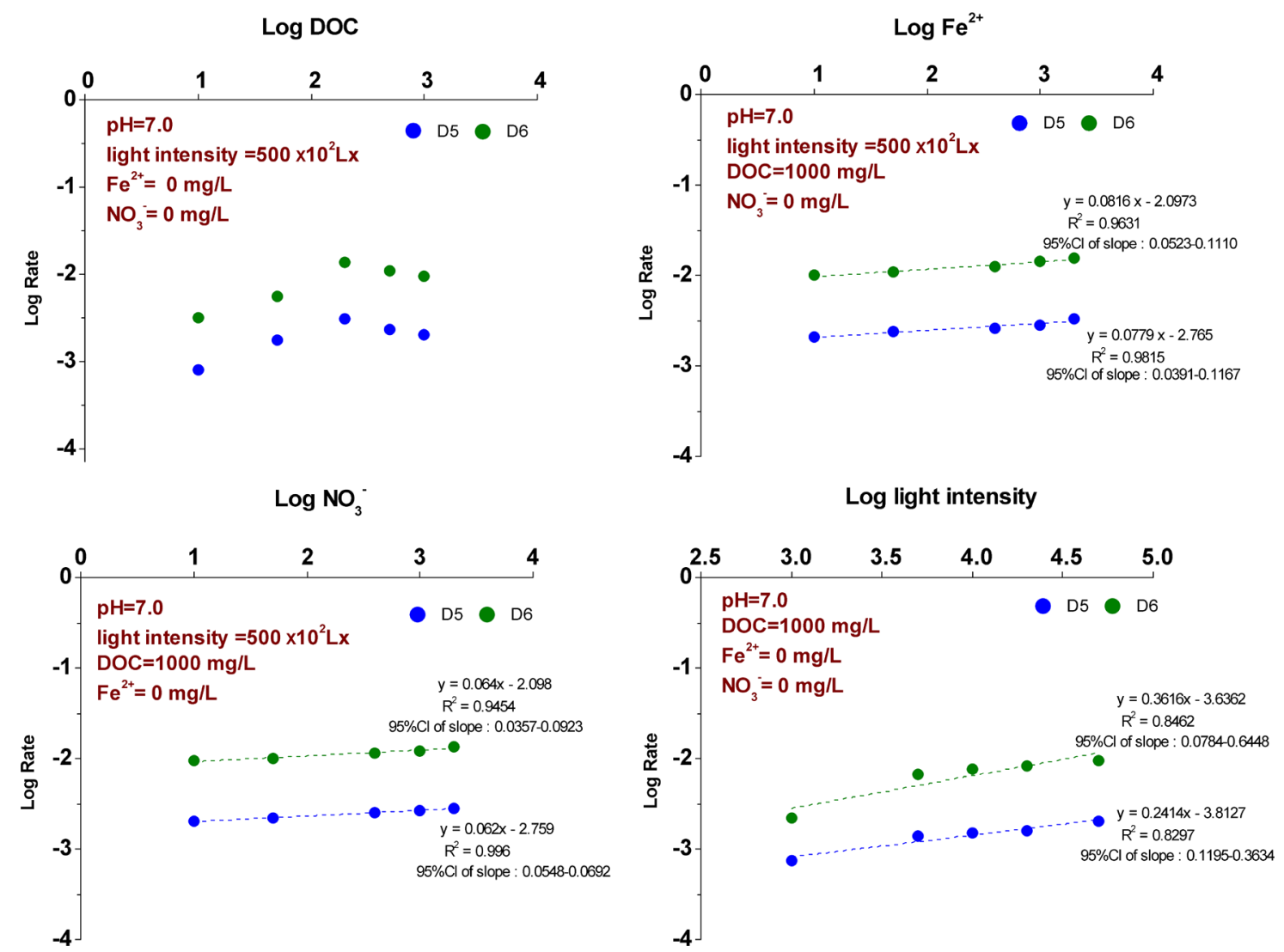

Figure 3. correlations between logarithms of the hydroxylation rate constants (unit:1/d) of cVMS and logarithms of leachate chemical characteristics (DOC, $\mathrm{Fe}^{2+}$ and $\mathrm{NO}_{3}^{-}$) and light intensity

Table 1. First-Order Removal Rates of Compounds in Simulated Leachate

\begin{tabular}{|c|c|c|c|c|c|c|c|c|}
\hline & \multicolumn{2}{|c|}{ total removal } & \multicolumn{2}{|c|}{ volatilization } & \multicolumn{2}{|c|}{ hydrolysis } & \multicolumn{2}{|c|}{ phototransformation } \\
\hline & rate constant $\left(\mathrm{d}^{-}\right)$ & half-life (days) & rate constant $\left(\mathrm{d}^{-}\right)$ & half-life (days) & rate constant $\left(\mathrm{d}^{-}\right)$ & half-life (days) & rate constant $\left(\mathrm{d}^{-}\right)$ & half-life (days) \\
\hline D4TOH & $4.49 \times 10^{-2}$ & 6.66 & $3.49 \times 10^{-3}$ & 86.3 & $4.01 \times 10^{-2}$ & 7.50 & $1.30 \times 10^{-3}$ & 231 \\
\hline D5TOH & $1.96 \times 10^{-2}$ & 15.4 & $1.70 \times 10^{-3}$ & 177 & $1.40 \times 10^{-2}$ & 21.5 & $3.87 \times 10^{-3}$ & 77.8 \\
\hline D5 & $1.88 \times 10^{-2}$ & 16.0 & $1.02 \times 10^{-2}$ & 29.4 & $5.62 \times 10^{-3}$ & 53.6 & $2.98 \times 10^{-3}$ & 101 \\
\hline D6 & $1.37 \times 10^{-2}$ & 22.0 & $2.33 \times 10^{-3}$ & 129 & $1.41 \times 10^{-3}$ & 214 & $9.96 \times 10^{-3}$ & 30.2 \\
\hline
\end{tabular}

(0.84-1.15\%, 0.96\% at mean) and D5TOH (3.01-6.39\%, 4.41\% at mean) to parent cVMS in the collected leachates. The above phenomenon could be caused by several reasons, for examples: (1) phototransformation products of D5 and D6 included other compounds besides D4TOH and D5TOH; (2) D4TOH and D5TOH were unstable and would undergo further removal in storage pond. In this section, we focused on removal mechanisms of D4TOH and D5TOH in leachates through simulated experiments (Section 2.5.4). Based on semilog plots of their concentrations versus incubation time (SI Figure S8), the first-order volatilization and degradation rates of $\mathrm{D} 4 \mathrm{TOH}$ and $\mathrm{D} 5 \mathrm{TOH}$ were calculated with the same methods for cVMS (Section 3.2).

Overall, half-lives of D4TOH (6.66 days) and D5TOH (15.4 days) in opened leachates under illumination were 2.4 and 1.4 times shorter than those of paired methylsiloxanes ( 16.0 days for D5, 22.0 days for D6), respectively (Table 1). However, volatilization rates of $\mathrm{D} 4 \mathrm{TOH}\left(k=3.49 \times 10^{-3} \mathrm{~d}^{-1}, t_{1 / 2}=\right.$ 86.3 days $)$ and $\mathrm{D} 5 \mathrm{TOH}\left(k=1.70 \times 10^{-3} \mathrm{~d}^{-1}, t_{1 / 2}=177\right.$ days $)$ were 2.9 and 1.4 times lower than those of paired D5 $(k=1.02 \times$ $10^{-2} \mathrm{~d}^{-1}, t_{1 / 2}=29.4$ days $)$ and D6 $\left(k=2.33 \times 10^{-3} \mathrm{~d}^{-1}, t_{1 / 2}=\right.$ 129 days), respectively (Table 1 ), which should be because $-\mathrm{OH}$ has stronger hydrophilicity than $-\mathrm{CH}_{3}$. These results meant that besides volatilization, there would be competing removal mechanism (degradation) for $\mathrm{D} 4 \mathrm{TOH}$ and $\mathrm{D} 5 \mathrm{TOH}$, less significant for D5 and D6 under such conditions.

Under nonillumination, the removal rates of $\mathrm{D} 4 \mathrm{TOH}$ and $\mathrm{D} 5 \mathrm{TOH}$ in capped leachate were approximately equal to those in paired sterile samples (SI Figure S8), indicating their negligible anaerobic biodegradation- the dominant biodegradation pathway of organic chemicals in leachate. After incubation for 48 days in capped leachate under nonillumination, total silicon mass of dimethylsilanediol and methylsilanetriol approximately accounted for $51.5 \%$ and $40.4 \%$ of spiked D4TOH and D5TOH, respectively (SI Figure S9), suggesting that hydrolysis was one important elimination pathways of D4TOH and D5TOH in such condition. Because $-\mathrm{OH}$ had stronger electrophilicity than $-\mathrm{CH}_{3}, \mathrm{Si}-\mathrm{O}$ bond with one branch of $-\mathrm{OH}$ would be more polar and easier to undergo bond cleavage via acid/alkaline catalysis than $\mathrm{Si}-\mathrm{O}$ bond merely linked with branches of $-\mathrm{CH}_{3}$, which may explain why hydrolysis rates of D4TOH $(k=4.01 \times$ $10^{-2} \mathrm{~d}^{-1}, t_{1 / 2}=7.50$ days $)$ and D5TOH $\left(k=1.40 \times 10^{-2} \mathrm{~d}^{-1}, t_{1 / 2}=\right.$ 21.5 days) were 7.1 and 10 times faster than those paired methylsiloxanes D5 $\left(k=5.62 \times 10^{-3} \mathrm{~d}^{-1}, t_{1 / 2}=53.6\right.$ days $)$ and D6 $\left(k=1.41 \times 10^{-3} \mathrm{~d}^{-1}, t_{1 / 2}=214\right.$ days $)$, respectively (Table 1$)$. 
The calculated phototransformation rates of $\mathrm{D} 4 \mathrm{TOH}$ $\left(k=1.30 \times 10^{-3} \mathrm{~d}^{-1}, t_{1 / 2}=231\right.$ days $)$ and D5TOH $(k=3.87 \times$ $10^{-3} \mathrm{~d}^{-1}, t_{1 / 2}=77.8$ days) were 2.3 and 2.6 times lower than those of their corresponding D5 $\left(k=2.98 \times 10^{-3} \mathrm{~d}^{-1}, t_{1 / 2}=101\right.$ days $)$ and D6 $\left(k=9.96 \times 10^{-3} \mathrm{~d}^{-1}, t_{1 / 2}=30.2\right.$ days $)$, respectively (Table 1 ), which could explain why no other hydroxylated product of D5 and D6, besides monohydroxylated products (D4TOH and D5TOH), was found in both EI and PCI full scan chromatogram for leachates under illumination (SI Figure S7).

\section{ASSOCIATED CONTENT}

\section{S Supporting Information}

The Supporting Information is available free of charge on the ACS Publications website at DOI: 10.1021/acs.est.7b03624.

Details of experiment methods physical/chemical characteristics of landfill, concentrations of target compounds in both landfill and WWTP, and elimination curves of target compounds under various conditions (PDF)

\section{AUTHOR INFORMATION}

\section{Corresponding Author}

*Phone: +86 (10) 62849182; fax: 8610-62849182; e-mail: caiyaqi@rcees.ac.cn.

\section{ORCID}

Lin Xu: 0000-0002-4681-6457

Yaqi Cai: 0000-0002-2805-5535

\section{Notes}

The authors declare no competing financial interest.

\section{ACKNOWLEDGMENTS}

This work was supported by National Natural Science Foundation of China (21537004, 21377145, 21621064) and the Strategic Priority Research Program of the Chinese Academy of Sciences (XDB14010201). We are grateful to Dr. Yawei Wang from Research Center for Eco-Environmental Sciences, Chinese Academy of Sciences, for his help in Q-TOF GC/MS analysis.

\section{REFERENCES}

(1) Brook, D. N.; Crookes, M. J.; Gray, D.; Robertson, S. Environmental Risk Assessment Report: Octamethylcyclotetrasiloxane; Environment Agency of England and Wales, Bristol, UK. 2009a.

(2) Brook, D. N.; Crookes, M. J.; Gray, D.; Robertson, S. Environmental Risk Assessment Report: Decamethylcyclopentasiloxane; Environment Agency of England and Wales: Bristol, UK. 2009b.

(3) Brook, D. N.; Crookes, M. J.; Gray, D.; Robertson, S. Environmental Risk Assessment Report: Dodecamethylcyclohexasiloxane; Environment Agency of England and Wales: Bristol, UK. 2009c.

(4) Dewil, R.; Appels, L.; Baeyens, J.; Buczynska, A.; Vaeck, L. V. The analysis of volatile siloxanes in waste activated sludge. Talanta 2007, 74 (1), 14-19.

(5) Wang, D. G.; Steer, H.; Tait, T.; Williams, Z.; Pacepavicius, G.; Young, T.; Ng, T.; Smyth, S. A.; Kinsman, L.; Alaee, M. Concentrations of cyclic volatile methylsiloxanes in biosolid amended soil, influent, effluent, receiving water, and sediment of wastewater treatment plants in Canada. Chemosphere 2013, 93 (5), 766-773.

(6) Sanchís, J.; Martínez, E.; Ginebreda, A.; Farré, M.; Barceló, D. Occurrence of linear and cyclic volatile methylsiloxanes in wastewater, surface water and sediments from Catalonia. Sci. Total Environ. 2013, $443,530-538$.

(7) Bletsou, A. A.; Asimakopoulos, A. G.; Stasinakis, A. S.; Thomaidis, N. S.; Kannan, K. Mass loading and fate of linear and cyclic siloxanes in a wastewater treatment plant in Greece. Environ. Sci. Technol. 2013, 47 (4), 1824-1832.
(8) Lee, S.; Moon, H. B.; Song, G. J.; Ra, K.; Kannan, K. A nationwide survey and emission estimates of cyclic and linear siloxanes through sludge from wastewater treatment plants in Korea. Sci. Total Environ. 2014, 497-498, 106-112.

(9) Wang, D. G.; Aggarwal, M.; Tait, T.; Brimble, S.; Pacepavicius, G.; Kinsman, L. Fate of anthropogenic cyclic volatile methylsiloxanes in a wastewater treatment plant. Water Res. 2015, 72, 209-217.

(10) Kierkegaard, A.; Egmond, R. V.; Mclachlan, M. S. Cyclic volatile methylsiloxane bioaccumulation in flounder and ragworm in the Humer Esturary. Environ. Sci. Technol. 2011, 45, 5936-5942.

(11) El-Fadel, M.; Findikakis, A. N.; Leckie, J. O. Environmental impacts of solid waste landfilling. J. Environ. Manage. 1997, 50, 1-25.

(12) Paxéus, N. Organic compounds in municipal landfill leachates. Water Sci. Technol. 2000, 42, 323-333.

(13) TemaNord, 2005, Siloxanes in the Nordic Environment. TemaNord 2005:593., Copenhagen:Nordic Council of Ministers.

(14) Schweigkofler, M.; Niessner, R. Determination of siloxanes and VOC in landfill gas and sewage gas by canister sampling and GC-MS/ AES analysis. Environ. Sci. Technol. 1999, 33, 3680-3685.

(15) McBean, E. A. Siloxanes in biogases from landfills and wastewater digesters. Can. J. Civ. Eng. 2008, 35, 431-436.

(16) Cheng, Y.; Shoeib, M.; Ahrens, L.; Harner, T.; Ma, J. Wastewater treatment plants and landfills emit volatile methyl siloxanes (VMSs) to the atmosphere: Investigations using a new passive air sampler. Environ. Pollut. 2011, 159, 2380-2386.

(17) Benskin, J. P.; Li, B.; Ikonomou, M. G.; Grace, J. R.; Li, L. Y. Perand polyfluoroalkyl substances in landfill leachate: Patterns, time trends, and sources. Environ. Sci. Technol. 2012, 46, 11532-11540.

(18) Ministry of housing and Urban-Rural Development of the People's Republic of China. Technical code for leachate treatment of municipal solid waste. CJJ150-2010.2011.

(19) Tsarpali, V.; Kamilari, M.; Dailianis, S. Seasonal alterations of landfill leachate composition and toxic potency in semi-arid regions. J. Hazard. Mater. 2012, 233-234, 163-171.

(20) Vione, D.; Falletti, G.; Maurino, V.; Minero, C.; Pelizzetti, E.; Malandrino, M.; Ajassa, R.; Olariu, R.-I.; Arsene, C. Sources and sinks of hydroxyl radicals upon irradiation of natural water samples. Environ. Sci. Technol. 2006, 40, 3775-3781.

(21) Vaughan, P. P.; Blough, N. V. Photochemical formation of hydroxyl radical by constituents of natural waters. Environ. Sci. Technol. 1998, 32, 2947-2953.

(22) Vione, D.; Minella, M.; Maurino, V.; Minero, C. Indirect photochemistry in sunlit surface waters: Photoinduced production of reactive transient species. Chem. - Eur. J. 2014, 20, 10590-10606.

(23) Meeroff, D. E.; Lakner, J. Safe Discharge of Landfill Leachate to the Environment." Final Report for the William W, Report \#1332027-A; "Bill" Hinkley Center for Solid and Hazardous Waste Management: Gainesville, FL, 2014.

(24) Zepp, R. G.; Faust, B. C.; Hoigné, J. Hydroxyl Radical Formation in Aqueous Reactions ( $\mathrm{pH} 3-8$ ) of Iron(I I) with Hydrogen Peroxide: The Photo-Fenton Reaction. Environ. Sci. Technol. 1992, 26, 313-319.

(25) Atkinson, R. Kinetics of the gas-phase reactions of a series of organosilicon compounds with $\mathrm{OH}$ and $\mathrm{NO}_{3}$ radicals and $\mathrm{O}_{3}$ at $297 \pm$ 2K. Environ. Sci. Technol. 1991, 25, 863-866.

(26) Sommerlade, R.; Parlar, H.; Wrobel, D.; Kochs, P. Product analysis and kinetics of the gas-phase reactions of selected organosilicon compounds with $\mathrm{OH}$ radicals using a smog chamber-mass spectrometer system. Environ. Sci. Technol. 1993, 27, 2435-2440.

(27) MacLeod, M.; Kierkegaard, A.; Harner, T.; Scheringer, M. Junge relationships in measurement data for cyclic siloxanes in air. Chemosphere 2013, 93 (5), 830-834.

(28) Eaton, A.D.; Clesceri, L.S.; Grenberg, A.E. Standard Methods for the Examination of Water and Wastewater, 19th ed.; APHA, AWWA, WEF: MD, 1995.

(29) D'Elia, C. F.; Steudler, P. A. Determination of total nitrogen in aqueous samples using persulfate digestion. Limnol. Oceanogr. 1977, 22, $760-764$.

(30) US-EPA method 6010C. Inductively Coupled Plasma-Atomic Emission Spectrometry. 
(31) Shi, Y. L.; Xu, S.; Xu, L.; Cai, Y. Q. Distribution, elimination, and rearrangement of cyclic volatile methylsiloxanes in oil-contaminated soil of the Shengli Oilfield, China. Environ. Sci. Technol. 2015, 49 (19), $11527-11535$.

(32) Xu, L.; He, X. D.; Zhi, L. Q.; Zhang, C. H.; Zeng, T.; Cai, Y. Q. Chlorinated methylsiloxanes generated in the papermaking process and their fate in wastewater treatment process. Environ. Sci. Technol. 2016, 50 (23), 12732-12741.

(33) Guerard, J. J.; Chin, Y. P. Photodegradation of ormetoprim in aquaculture and stream-derived dissolved organic matter. J. Agric. Food Chem. 2012, 60, 9801-9806.

(34) Hartz, K. E.; Klink, R. E.; Ham, R. K. Temperature effects: methane generation from landfill samples. J. Environ. Eng. Div. (Am. Soc. Civ. Eng.) 1982, 108 (4), 629-638.

(35) Xu, L.; Shi, Y.; Cai, Y. Occurrence and fate of volatile siloxanes in a municipal Wastewater Treatment Plant of Beijing, China. Water Res. 2013, 47, 715-724.

(36) Kim, D. J.; Lee, D. I.; Keller, J. Effect of temperature and free ammonia on nitrification and nitrite accumulation in landfill leachate and analysis of its nitrifying bacterial community by FISH. Bioresour. Technol. 2006, 97, 459-468.

(37) Sahm, H.; Fiechter, A. Adv. Biochem. Eng. Biotechnol. 1984, 29, 83-115.

(38) Zepp, R. G.; Braun, A. M.; Hoigné, J.; Leenheer, J. A. Photoproduction of hydrated electrons from natural organic solutes in aquatic environments. Environ. Sci. Technol. 1987, 21, 485-490.

(39) Mcneill, K. Themed issue on aquatic photochemistry. Environ. Sci.: Processes Impacts 2014, 16, 626-878. 